УДК 636.5.033:612.12:631.147, DOI 10.31210/visnyk2018.04.25

(C) 2018

Кучерук М. Д., кандидат ветеринарних наук,

Засєкін Д. А., доктор ветеринарних наук, професор

Національний університет біоресурсів і природокористування України

\title{
КЛІНІЧНІ Й ГЕМАТОЛОГІЧНІ ПОКАЗНИКИ КУРЧАТ-БРОЙЛЕРІВ ЗА ОРГАНІЧНОГО ВИРОЩУВАННЯ
}

\section{Рецензент - доктор ветеринарних наук, професор Л. В. Шевченко}

Стаття присвячена вивченню можливості вирощування курчат-бройлерів органічним способом для отримання якісної та безпечної курятини. Здійснено порівняння прочесу вирощування, динаміки набору живої маси курчат органічного вирощування з традииійною інтенсивною технологією. Акцентовано висвітлено питання зміни біохімічних та морфологічних показників периферичної крові в динамічі. Проведеними дослідженнями патологічних відхилень у картині крові курчат різного віку не виявлено. Певні коливання відповідали віковим періодам росту й розвитку, а також деякому впливу стрес-факторів зовнішнього середовища. Гуманна складова органічного вирощування курей перекриває економічні видатки, пов'язані з більш тривалим періодом утримання, а органічна продукція має додану вартість. Однак лише створення належних умов утримання $i$ догляду птиці для задоволення їх природних потреб, годівля натуральними, екологічно чистими кормами в кінцевому результаті дозволяє отримати якісну й безпечну органічну продукцію.

Ключові слова: біохімічні, гематологічні показники, курчата-бройлери, органічне виробничтво.

Постановка проблеми. Якість і безпечність продуктів харчування турбує кожного пересічного споживача перш за все. Однак для виробників продукції прагнення до високої рентабельності виробництва і швидкого повернення інвестицій часто затьмарює важливість отримання якісного кінцевого харчового продукту.

В умовах поступового погіршення екологічного стану навколишнього середовища, обумовленого нераціональною інтенсифікацією промисловості, перед Україною гостро постають питання виробництва й споживання екологічно чистих товарів, у першу чергу, для задоволення потреб населення країни.

За останні десятиліття якість і безпечність продуктів харчування поступово відходили на другий план, поступаючись ціновій доступності для споживача.

Однак кожен, хто дбає про своє здоров'я, намагається споживати кращі продукти, адже «ми $€$ те, що ми їмо».
Аналіз останніх досліджень і публікацій, у яких започатковано розв'язання проблеми. На жаль, м'ясо тварин, вирощених за інтенсивних технологій виробництва, не завжди є корисним, оскільки вони страждають від ожиріння, хвороб, неможливості задоволення природних потреб і негуманного ставлення. Часто це м'ясо $€$ небезпечним через уміст антибіотиків, пестицидів тощо. Із продукцією птахівництва хімікати, які застосовуються на фермах, потрапляють в організм людини [6].

Продуктивність, благополуччя та здоров'я сільськогосподарських тварин залежать не тільки від годівлі, але й від умов утримання та догляду [1].

На сьогодні існує реальна необхідність перегляду ставлення людей до тварин, зокрема сільськогосподарських. У науковій літературі досить широко описано негативні наслідки інтенсифікації вирощування курчат м'ясних кросів за неналежного утримання. У світі й Україні існують волонтерські зоозахисні організації, що відстоюють права та свободи тварин, зокрема птиці [7].

3 фізіологічної точки зору, відстежити вплив певного чиннику на механізми регуляції метаболічного гомеостазу внутрішнього середовища організму та продуктивність птиці допомагають гематологічні дослідження [2].

Кров відіграє виключно важливу роль у біохімічних процесах, що протікають в організмі птиці. Вона $є$ основним індикатором, що характеризує метаболізм, виконує трофічну, екскреторну, респіраторну, захисну, теплорегулюючу, а також корелятивну функції. Окрім змін, пов'язаних із порою року, фазами росту та продуктивністю (наприклад початок яйцекладки), вгодованістю, біохімічні та морфологічні показники крові реагують навіть на зміну умов утримання (вигул на пасовищі), загазованість повітря чи його мікробне навантаження, нестачу кисню, голодування чи взяття крові у нагодованої птиці, впливу стрес-факторів тощо [4]. 


\section{ВЕТЕРИНАРНА МЕДИЦИНА}

Склад крові є одним із найбільш лабільних показників функціонального стану організму птиці, швидко і точно реагує на введення в корм різних добавок. Біохімічні процеси протікають за безпосередньої участі специфічних для кожної біохімічної реакції ферментів і гормонів. Всі процеси обміну взаємопов'язані [3]. Зміни їх інтенсивності в ланках одного обміну відображаються на всіх інших видах обміну. За складного і тісного взаємозв'язку всіх видів обміну існує загальнобіологічна закономірність.

Біохімічними дослідженнями, навіть на ранніх стадіях захворювання, можливо виявити відхилення у всіх видах обміну речовин.

Так, кількість еритроцитів і їх насиченість гемоглобіном характеризують киснезв'язувальні властивості крові й рівень окислювальновідновлювальних процесів в організмі бройлерів. Крім того, еритроцити, адсорбуючи отрути, $\epsilon$ захисними клітинами організму, містять аглютиноген (антигени А і В), адсорбують цукор, амінокислоти, поліпептиди, загальний, залишковий азот і багато інших речовин [5]. Зміни вмісту білка і білкових фракцій у сироватці крові бройлерів можуть бути індикатором стану білкового обміну і змін в їх печінці тощо [3].

Мета: дослідити зміни метаболічного гомеостазу внутрішнього середовища організму за органічного вирощування.

Завдання: оцінити гематологічні показники курчат-бройлерів, їх відповідність нормативним значенням.

Матеріали і методи досліджень. Для проведення досліджень було використано курчат кросу Кобб-500. Органічне вирощування курчат організували в умовах діючого органічного господарства (Житомирська область). Курчата утримувались на теплій підлозі з тирсовою підстилкою та мали можливість за належних погодних умов виходити на вигульні майданчики, вкриті рослинністю. Антибіотики 3 профілактичною метою не застосовувались. Період вирощування - 81 доба. Відбір крові для гематологічних досліджень здійснювали подекадно 3 підкрильцевої вени. Дослідження проводили за загальноприйнятими методами.

Статистичну обробку проводили за допомогою комп'ютерної програми Microsoft Excel [8].

Результати досліджень. На відміну від курчат інтенсивного вирощування на птахофабриці, де курчата швидко набирали вагу 2-2,5 кг за сорок два дні, курчата органічного вирощування набирали вагу впродовж 81 доби, поступово, що $\epsilon$ природньо й сприятливо для фізіологічного росту і розвитку всіх систем організму. Це підтверджується клінічними спостереженнями за станом здоров'я поголів'я та гематологічною картиною.

Швидкість росту й набору живої маси, перш за все, залежить від годівлі птиці. Раціон курчат за органічного вирощування не був ідеально збалансованим за поживністю, хоча відповідав потребі курчат за віком. Цей раціон складався виключно з органічних складників, що було підтверджено сертифікатами, не містив ГМО, синтетичних амінокислот та пестицидів. Птиця за вільновигульного утримання менше споживає комбікормів, має більшу рухову активність протягом доби, на відміну від традиційного вирощування курчат-бройлерів, де курчата не користуються моціоном і мають обмежений простір для руху. До 30 діб життя курчата не користувались моціоном і дещо в більшій мірі споживали корм. Починаючи 3 вигульного періоду, споживання корму значно зменшилось. Отже, приріст живої маси відбувався не так інтенсивно, що відобразилося й на гематологічних показниках.

Біохімічні зміни в організмі відбувались і за фазами вирощування. Кількість загального білку крові (рис. 1) в обох групах була в межах фiзioлогічної норми і корелювала з вмістом гемоглобіну й кількістю еритроцитів.

Як видно 3 таблиці 1, переведення курчат на вигульні майданчики, як стрес-фактор, позначилось на вмісті загального білку та гемоглобіну в крові. Їх кількість на 40-ву добу вирощування зменшилась, порівняно 30-ю добою. А морфологічні дослідження підтвердили зменшення кількості еритроцитів у картині крові на фоні стресу від переведення в нові умови утримання. Оскільки зниження відбулось несуттєве, а фізіологічних відхилень і захворювань в цей період не було зафіксовано, дані зміни можна пояснити, на нашу думку, виключно стресовим станом у випадку переводу курчат на пасовище.

Однак вже на 50-ту добу вирощування кількість еритроцитів в крові зросла. Разом із тим, цей показник на 50-ту добу був наближений до граничних значень норми. Це пов'язано, на нашу думку, із критичними значеннями температури зовнішнього середовища. В цей період вона становила від 33 до $36^{\circ} \mathrm{C}$ в тіні. А оскільки нормувати температуру (за допомогою вентиляторів та кондиціонерів) на пасовищі неможливо, до того ж вода в напувалках теж дуже швидко нагрівалася й курчата неохоче іiі споживали, не маючи можливості охолодитися, - відбулося незначне згущення крові на фоні зневоднення. 


\section{ВЕТЕРИНАРНА МЕДИЦИНА}

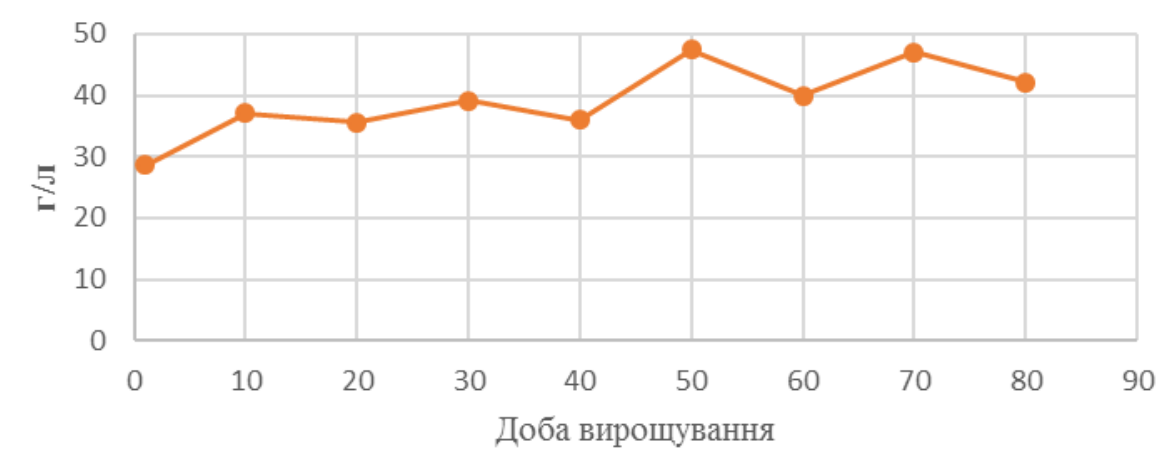

Рис. 1. Порівняння динаміки змін вмісту загального білку в крові курчат-бройлерів за періодами вирощування, г/л.

1. Гематологічні показники курчат за органічного вирощування, $M \pm m, n=5$

\begin{tabular}{|c|c|c|c|c|c|c|c|c|c|}
\hline \multirow{2}{*}{ Показник } & \multicolumn{9}{|c|}{ Доба вирощування } \\
\hline & 1 & 10 & 20 & 30 & 40 & 50 & 60 & 70 & 80 \\
\hline Еритроцити, Т/л & $\begin{array}{c}1,70 \pm \\
0,35\end{array}$ & $\begin{array}{c}1,90 \pm \\
0,28\end{array}$ & $\begin{array}{c}1,90 \pm \\
0,25\end{array}$ & $\begin{array}{c}2,00 \pm \\
0,30\end{array}$ & $\begin{array}{c}1,90 \pm \\
0,28\end{array}$ & $\begin{array}{c}2,40 \pm \\
0,25\end{array}$ & $\begin{array}{c}2,10 \pm \\
0,27\end{array}$ & $\begin{array}{c}2,30 \pm \\
0,35\end{array}$ & $\begin{array}{c}2,10 \pm \\
0,43\end{array}$ \\
\hline Гемоглобін, г/л & $\begin{array}{c}67,00 \pm \\
3,90\end{array}$ & $\begin{array}{c}70,20 \pm \\
4,40\end{array}$ & $\begin{array}{c}71,40 \pm \\
3,70\end{array}$ & $\begin{array}{c}80,10 \pm \\
4,20\end{array}$ & $\begin{array}{c}78,30 \pm \\
5,40\end{array}$ & $\begin{array}{c}105,10 \pm \\
6,90\end{array}$ & $\begin{array}{c}80,40 \pm \\
5,80\end{array}$ & $\begin{array}{c}79,70 \pm \\
4,50\end{array}$ & $\begin{array}{c}77,60 \pm \\
5,60\end{array}$ \\
\hline Лейкоцити, Г/л & $\begin{array}{c}25,14 \pm \\
1,30\end{array}$ & $\begin{array}{c}25,87 \pm \\
1,80\end{array}$ & $\begin{array}{c}27,09 \pm \\
1,50\end{array}$ & $\begin{array}{c}29,20 \pm \\
2,60\end{array}$ & $\begin{array}{c}28,60 \pm \\
1,95\end{array}$ & $\begin{array}{c}32,21 \pm \\
2,96\end{array}$ & $\begin{array}{c}32,80 \pm \\
3,70\end{array}$ & $\begin{array}{c}33,21 \pm \\
4,21\end{array}$ & $\begin{array}{c}36,78 \pm \\
3,91\end{array}$ \\
\hline Глюкоза, ммоль/л & $\begin{array}{c}8,83 \pm \\
0,63\end{array}$ & $\begin{array}{c}8,98 \pm \\
0,94\end{array}$ & $\begin{array}{c}8,82 \pm \\
0,83\end{array}$ & $\begin{array}{c}7,30 \pm \\
0,66\end{array}$ & $\begin{array}{c}9,19 \pm \\
1,11\end{array}$ & $\begin{array}{c}9,17 \pm \\
0,65\end{array}$ & $\begin{array}{c}12,00 \pm \\
0,82\end{array}$ & $\begin{array}{c}8,50 \pm \\
0,47\end{array}$ & $\begin{array}{c}13,73 \pm \\
1,73\end{array}$ \\
\hline Кальцій, ммоль/л & $\begin{array}{c}2,42 \pm \\
0,09\end{array}$ & $\begin{array}{c}1,74 \pm \\
0,40\end{array}$ & $\begin{array}{c}1,98 \pm \\
0,68\end{array}$ & $\begin{array}{l}1,3 \pm \\
0,15\end{array}$ & $\begin{array}{c}1,81 \pm \\
0,40\end{array}$ & $\begin{array}{c}2,89 \pm \\
0,56\end{array}$ & $\begin{array}{c}1,96 \pm \\
0,60\end{array}$ & $\begin{array}{c}2,59 \pm \\
0,37\end{array}$ & $\begin{array}{c}2,81 \pm \\
1,03\end{array}$ \\
\hline Фосфор, ммоль/л & $\begin{array}{c}1,16 \pm \\
0,03\end{array}$ & $\begin{array}{c}1,48 \pm \\
0,06\end{array}$ & $\begin{array}{c}1,47 \pm \\
0,04\end{array}$ & $\begin{array}{c}1,93 \pm \\
0,02\end{array}$ & $\begin{array}{c}2,70 \pm \\
0,12\end{array}$ & $\begin{array}{c}2,32 \pm \\
0,12\end{array}$ & $\begin{array}{c}2,61 \pm \\
0,24\end{array}$ & $\begin{array}{c}2,98 \pm \\
0,3\end{array}$ & $\begin{array}{c}3,10 \pm \\
0,21\end{array}$ \\
\hline
\end{tabular}

Шляхом спостереження встановлено, що за вище наведеної температури зовнішнього середовища птиця мало рухалася, сиділа з відкритим дзьобом, дихання було поверхневим та прискореним (теплова віддишка). Спекотні дні, до яких птиця не адаптована, є складним фактором для подолання в органічному птахівництві в умовах помірного клімату. Наслідком температурного стресу було зниження загального білку в крові курчат за органічного вирощування. Для підтвердження цього припущення було розраховано МCH (середній вміст гемоглобіну в еритроциті). На 40-ву добу він становив 41, на 50-ту - 42,08, на 60 -ту - 38,09. Отже, підвищення вмісту загального білку та гемоглобіну в крові відбулося на фоні дегідратації організму. Оскільки органічне вирощування максимально наближене до природних умов існування птиці, важко передбачити та уникнути таких небажаних явищ як перегрів та переохолодження курчат.

Динаміка коливань вмісту формених елемен- тів крові була в межах фізіологічної норми для курей повільноростучих порід (або молодняку курей-несучок). Значних відхилень, що свідчили б про порушення стану здоров'я птиці, не було встановлено.

За інтенсивного вирощування існує певна схема використання профілактичних, лікувальних препаратів, що компенсують відхилення продуктивності, пов'язані з погіршенням стану здоров'я птиці в процесі вирощування. Найчастіше це дисбактеріози різної етіології, гепатопатії, асцити грудної й черевної порожнин, опіки грудей та лап через надлишок аміаку в підстилковому матеріалі тощо. Різноманітні підтримуючі терапії (імуностимулятори, гепатопротектори, стимулятори вироблення білків, а також ферменти) в годівлі впливають на біохімічні й морфологічні показники крові курчат, можуть маскувати проблему й негативно впливати на якість кінцевого продукту. За органічного виробництва таких речовин не застосовують. 


\section{ВЕТЕРИНАРНА МЕДИЦИНА}

У віковій динаміці курчат-бройлерів за органічного вирощування відмічено хвилеподібні коливання показників глюкози й кальцію. Як видно 3 рисунка 2, на 30-ту добу зафіксовано зменшення вмісту глюкози в крові курчатбройлерів - період переведення на вигульні майданчики. Зменшення вмісту глюкози в крові курчат на 70-ту добу вирощування відмічено на фоні дещо підвищеного іiі вмісту на 60-ту. Однак у цілому різких стрибків та відхилень від норми біохімічних та морфологічних показників нами не встановлено.

Плавними були криві діаграм вмісту глюкози, як і вмісту загального білку, так й інших речовин, що досліджувались, зокрема ЛДГ (рис. 3), глюкоза, сечова кислота, що свідчить про поступовий і рівномірний ріст і розвиток організму курчат.

Активність лужної фосфатази зменшувалась 3 віком відповідно до нормативних значень показнику. Можемо припустити, що даний крос значно піддається впливу зовнішніх чинників (годівля, утримання) та стрес-факторів, що відображаються на біохімічних показниках.
Зведені в таблицю показники демонструють, що морфологічні та біохімічні показники крові птиці, вирощеної органічним способом, знаходилися в межах фізіологічної норми, однак більше були подібними до картини крові курейнесучок.

Висновок. За результатами клінічного спостереження, курчата-бройлери кросу Кобб-500 за органічного вирощування мали дещо нижчі прирости живої маси, однак в органічному птахівництві така швидкість росту птиці є допустимою через вимоги до благополуччя тварин. Патологічних відхилень в картині крові курчат виявлено не було, хоча вона була більш подібною до фізіологічної норми ремонтного молодняку курей-несучок.

Виявлено вплив факторів зовнішнього середовища (підвищена температура) на коливання фізіологічних й гематологічні показників птиці.

Подальші дослідження будуть проводитись на місцево адаптованій породі курей м'ясо-яєчного напряму за органічного вирощування. Термін вирощування для досягнення ними забійної маси буде розраховано аналогічно до ремонтного молодняку курей-несучок - близько 160-180 діб.

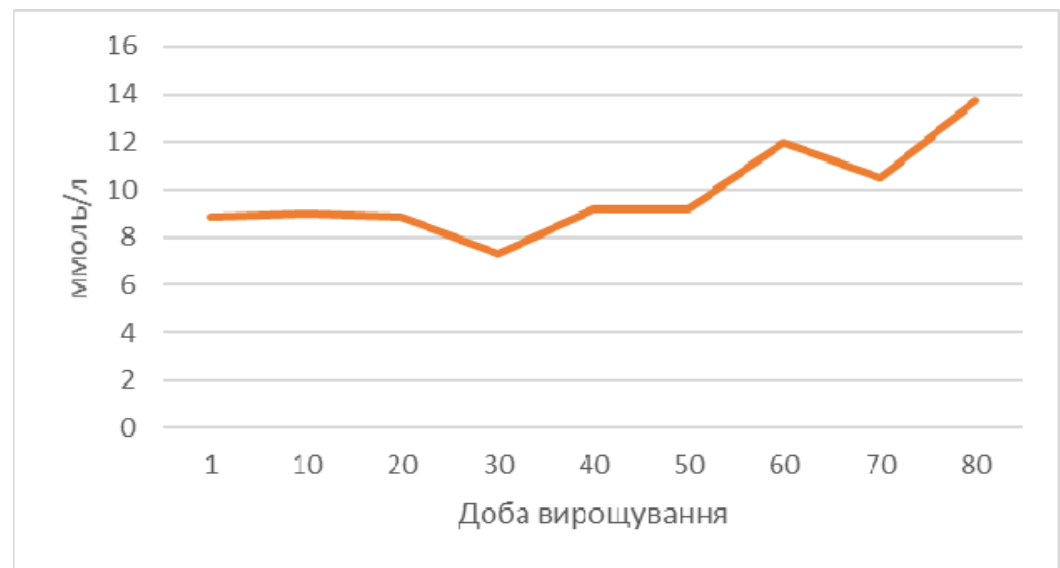

Рис. 2. Динаміка вмісту глюкози в крові курчат-бройлерів за періодами вирощування, ммоль/л

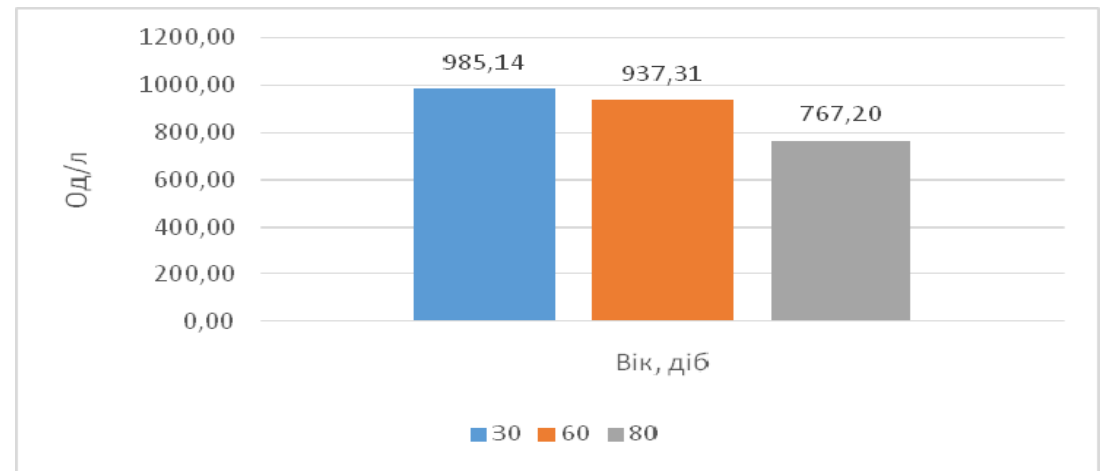

Рис. 3. Активність лужної фосфатази в крові курчат-бройлерів за органічного вирощування, Од/л 


\section{БІБЛІОГРАФІЯ}

1. Andrassyne B. G., Milisits G. et al. Effects of different rearing systems on muscle and meat quality traits of slow- and medium-growing male chickens. British Poultry Science, 2015. Volume 56 - Issue 3. - P. 320-324.

2. Maciorowski K. G., Ricke S. C., Birkhold S. G. Consumer poultry meat handling and safety education in three Texas cities. Poult. Sci., 1999. 78. - P. 833-840.

3. Sundrum A. Protein supply in organic poultry and pig production. Proceedings of the 1 st IFOAM International Conference on Animals in Organic Production, St. Paul, MN, Aug. 2325, 2006. - P. 195-199.

\section{ANNOTATION}

Kucheruk M. D., Zasiekin D. A. Clinic and hematological indices of broiler-chickens under organic growing.

The article is devoted to the study of the possibility of growing broiler-chickens in an organic way to produce high-quality and safe chicken. The growing process, the dynamics of a set of live weight of organic growing chickens are compared with the traditional intensive technology. Organic foods are healthier for consumers than traditional ones.

The productivity, well-being and health of farm animals depend not only on feeding, but also on the conditions of maintenance and care.

The hematological research promotes the study of the influence of a certain factor on the mechanisms of regulation of metabolic homeostasis of the internal environment of the organism and the productivity of the poultry. The issues of changes in the biochemical and morphological parameters of peripheral blood over time are highlighted.

Studies have not revealed pathological abnormalities in the blood picture of chickens of
4. Бойко Н. I. Дослідження морфології клітин крові у курей / Н. І. Бойко, Ю. В. Бойко, Р. В. Коханій, Р. П. Миколайчук // Сучасне птахівництво. - 2013. - №12. - С. 18-22.

5. Маикін Ю. О. Гематологічні та біохімічні показники крові курчат-бройлерів під впливом пробіотика «Протекто-Актив» / Ю. О. Машкін // Сучасне птахівництво. - 2010. - №1/2. - С. 26-28.

6. Наукові основи виробництва органічної продукції в Україні : кол. монографія / За ред. Я. М. Гадзала, В. Ф. Камінського. - К., 2016. - 596 с.

7. Організація Відкриті клітки Україна. Режим доступу : https://opencages.com.ua/.

different ages. Some fluctuations in blood glucose, as well as protein and hemoglobin, respectively, in most control points corresponded to age periods of growth and development, but also some influence of environmental stress factors (elevated air temperature) was noted. The dynamics of oscillations of blood cells was within the physiological norm for chickens of slowly growing breeds. Significant deviations testifying the violation of the health status of the poultry were not established.

The humane component of organic chicken raising covers the economic costs associated with a longer period of keeping and organic products have added value. However, only with the creation of proper conditions for the maintenance and care of poultry to meet their natural needs, when feeding with natural, environmentally friendly feed - you can ultimately receive high-quality and safe organic products.

Key words: biochemical, hematological parameters, chicken-broilers, organic production. 